\title{
Composite beams with aluminium girders - a review
}

\author{
M. Szumigała, M. Chybiński \& Ł. Polus \\ Institute of Building Engineering, Poznan University of Technology, Poznań, Poland
}

\begin{abstract}
This paper summarises a few years' research on the structural behaviour of composite beams with aluminium girders, i.e., aluminium-concrete composite beams and aluminium-timber composite beams. In the discussed systems, aluminium girders are connected to concrete or LVL slabs using demountable shear connectors. In this paper, the authors present a review of their theoretical, experimental and numerical analyses of the composite beams with aluminium girders. They also summarise the current state of knowledge on this topic.
\end{abstract}

\section{INTRODUCTION}

Nowadays, aluminium alloy structural members are widely used in civil engineering (Mazzolani 2006). Thanks to their lightness and durability, they can be used in domes, roofing, silos, tanks, bridges, towers, off-shore structures, pipelines and elevations (Siwowski 2006a, 2009) (Gwóźdź 2007) (Szumigała \& Polus 2015) (Kossakowski et al. 2017) (Lacki \& Derlatka 2017) (Chybiński et al. 2019a). Aluminium alloys have been used in composite structures since 1958, when the Clive Road Bridge - the first aluminium-concrete composite bridge - was erected. However, the use of aluminium alloys in composite structures is not popular due to the lack of applicable design rules. For this reason, composite structures with aluminium alloys are still being investigated.

\section{ALUMINIUM-CONCRETE COMPOSITE BEAMS}

Aluminium members and concrete members can be used within one structure. For example, bars and sheets made of aluminium have recently been used to strengthen reinforced concrete beams (Yu et al. 2020) ( $\mathrm{Xu}$ et al. 2020). A truss made of $7005 \mathrm{~T} 53$ aluminium alloy has been used with a concrete slab in a military bridge (Szelka \& Kamyk 2013) (Hanus et al. 2008). Furthermore, a column can be made by filling an aluminium tube with concrete (Zhou \& Young 2009). The concrete core improves both the member capacity and the fire resistance of the column, and the aluminium tube acts as a stay-in-place formwork (Chen et al. 2017).

An aluminium girder can be combined with a concrete slab to create an aluminiumconcrete composite (ACC) beam. ACC beams have been the subject of several studies. Bond tests on aluminium rods embedded in concrete, push-out tests of aluminium shear connectors and static bending tests of ACC beams with channel shear connectors were conducted by (Stonehewer 1962). The failure mode of the composite beams was associated with the yielding of the aluminium beam and the cracking and crushing of the concrete slab. Stonehewer showed that for beams with complete interaction between the concrete slab and the aluminium beam, the transformed section theory may be used to determine the strains. Two ACC beams with solid slabs were tested by (Bruzzese et al. 1989). The beams had identical geometric configurations, except for the stirrup spacing $(6.5 \mathrm{~cm}$ or $13.0 \mathrm{~cm})$. The stirrup spacing had an 
impact of the failure modes of the beams. The failure mode of the beam with the higher number of stirrups was associated with the damage of the compressed and tensioned edges of the concrete slab in the mid-span. The failure mode of the beam with the lower number of stirrups was associated with longitudinal and transverse fractures. A continuous span aluminium girder concrete deck bridge was tested by the researchers from Iowa State University (Abendroth et al. 1996). The results of the experimental study revealed that the strength properties of aluminium were sufficient for bridge girders. The deflections and strains measured in the 1993 field tests were in close agreement with the results of the pre-calculated values. Flexural behaviour of aluminium-lightweight concrete composite beams was investigated by Siwowski (2006b). Most of the studies performed on ACC structures to date have focused on systems in which solid slabs and non-demountable shear connectors were used.

A novel ACC beam, in which a concrete slab is poured into steel sheeting and connected with an aluminium beam using demountable shear connectors was presented by Polus \& Szumigała (2019a) (see Figure 1a). The profiled sheeting resists tension and acts as a stay-in-place formwork. A notable benefit of using demountable shear connectors is that they make it possible to separate aluminium girders from a concrete slab once the design life of the structure is over. Aluminium girders may later be reused or recycled. Headed studs and composite dowels are commonly used connectors but they are not demountable or they require labour-intensive processes to separate the components of the composite beam (Lee \& Bradford 2013) (Nijgh et al. 2018) (Szewczyk \& Szumigała 2018) (Kożuch \& Lorenc 2019). Furthermore, when demountable shear connectors are used, composite action is achieved without welding, which reduces the strength parameters of aluminium alloys in heat-affected zones. However, the bending resistance of unprotected ACC beams decreases very fast in a fire, e.g., the bending resistance of the ACC beam studied by Chybiński \& Polus (2018) decreased by $99.4 \%$ after a 15-minute car fire. Fire resistance may be increased by concreting aluminium girders in a similar way to concreting steel elements (Szmigiera 2007).

The load-slip behaviour of the demountable shear connectors was characterised in laboratory push-out tests. The slip modulus of the connection was low $\left(k_{0.4}=5.9 \mathrm{kN} / \mathrm{mm}\right)$ because of the clearance between the bolt and the hole (Polus \& Szumigała 2016). However, the clearance made it easier to install demountable shear connectors through the holes in the aluminium beam flange. The behaviour of the ACC beams with profiled sheeting and of said shear connectors was investigated in the bending tests by Polus \& Szumigała (2019a). The tested ACC beams showed signs of rib-shearing failure. For this reason, the use of profiled sheeting with a greater rib width, and the use of the waveform reinforcement showed by Patrick (2000) is recommended to prevent such failure in the future. Furthermore, the calculation procedure for steel-concrete composite elements was used to calculate the load-carrying capacity of the ACC beams. The bending resistance of the ACC beam from the analytical estimations was 1.05 times higher than the bending resistance from the tests (Polus \& Szumigała 2019a). What is more, non-linear 3D finite element models of the ACC elements used in the bending test and

a)

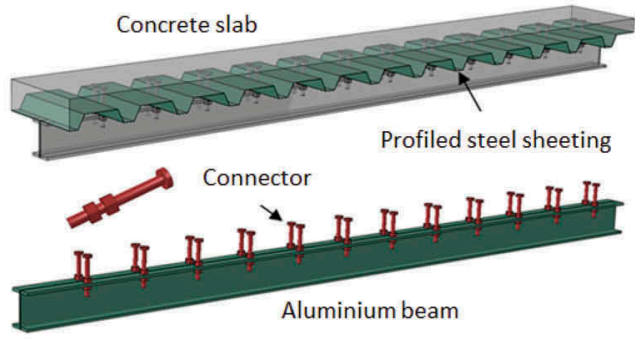

b)

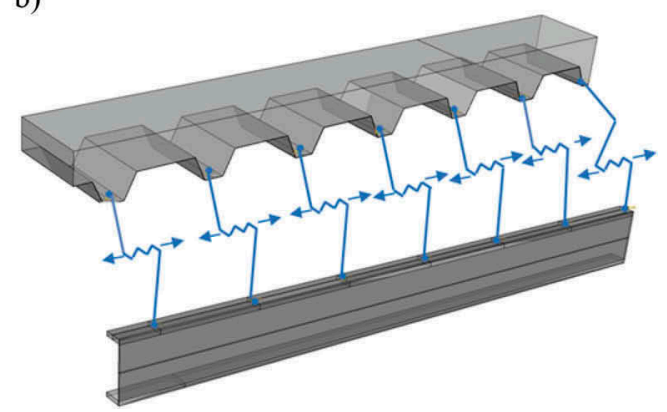

Figure 1. The aluminium-concrete composite beam tested by (Polus \& Szumigała 2019a): a) beam parts, b) a quarter of the beam with zero-length springs. 
in the push-out test were developed and verified against the experimental results. The shear connectors were modelled using zero-length springs (see Figure 1b). As a result, the slip between the aluminium beam and the concrete slab was taken into account (Polus \& Szumigała 2019a). Discrete springs were used to model connections by Hassanieh et al. (2016), Kyvelou et al. (2018), Studziński \& Ciesielczyk (2019), Polus \& Szumigała (2019b), Chybiński et al. (2019b) and by Abramowicz et al. (2020). They provided reasonable accuracy. The comparison of the numerical and experimental analyses demonstrated that the adopted numerical models captured the responses of the beams and their joints relatively well (Polus \& Szumigała 2019a).

\section{ALUMINIUM-TIMBER COMPOSITE BEAMS}

An aluminium girder can be combined with a timber slab to create an aluminium-timber composite (ATC) beam. ATC beams have been the subject of several studies. Bending tests on ATC beams with screws and plywood slabs were conducted by (Saleh \& Jasim 2014). Recently, the flexural behaviour of ATC beams with laminated veneer lumber (LVL) slabs has been investigated by (Szumigała et al. 2017, 2019) (Chybiński \& Polus 2019) (see Figure 2).

The advantages of using ATC beams instead of steel-concrete composite beams include reduced construction time, small self-weight and high durability of aluminium girders. Furthermore, LVL has fewer defects than solid wood (Komorowski 2017). However, the problem of stresses evoked by temperature change in ATC beams calls for more investigations (Marcinowski 2018). Aluminium beams may be combined with LVL slabs using screws or bolts.

The load-slip behaviour of the screw connections in ATC beams was characterised in laboratory push-out tests (Chybiński \& Polus 2019). The failure mode of the screw connection was associated with the crushing of the timber, the formation of one plastic hinge within the connector at the aluminium-timber interface and the hole ovalisation in the flange of the aluminium beam (see Figure 3). The behaviour of the ATC beams was studied in bending tests by Chybiński and Polus (2019) (see Figure 4). The failure mode of the ATC beams was associated with LVL damage. The veneers separated from each other in the tensioned parts of the LVL slabs and cambered in the compressed parts.

Furthermore, the calculation procedure for steel-concrete composite elements was used to calculate the load-carrying capacity of the ATC beams. The bending resistance of the ATC composite beam from the analytical estimations was 1.08 times lower than the bending resistance from the tests (Chybiński \& Polus 2019). What is more, the non-linear three-dimensional

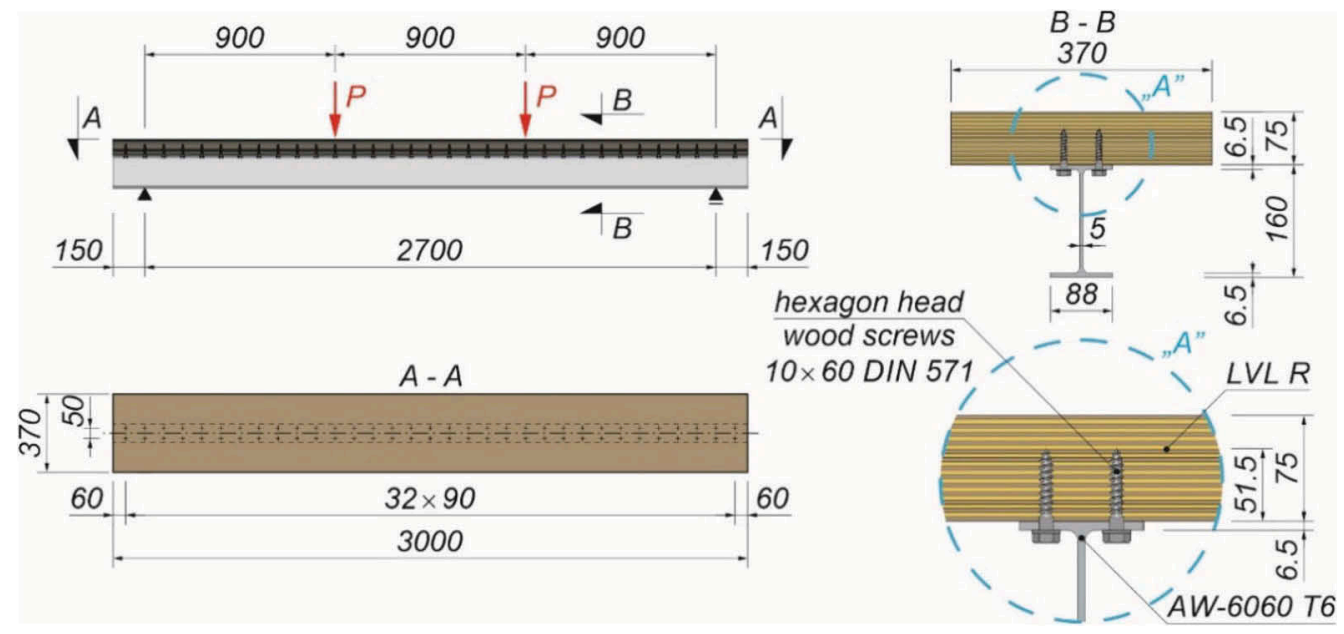

Figure 2. The aluminium-timber composite beam tested by (Chybiński \& Polus 2019). 

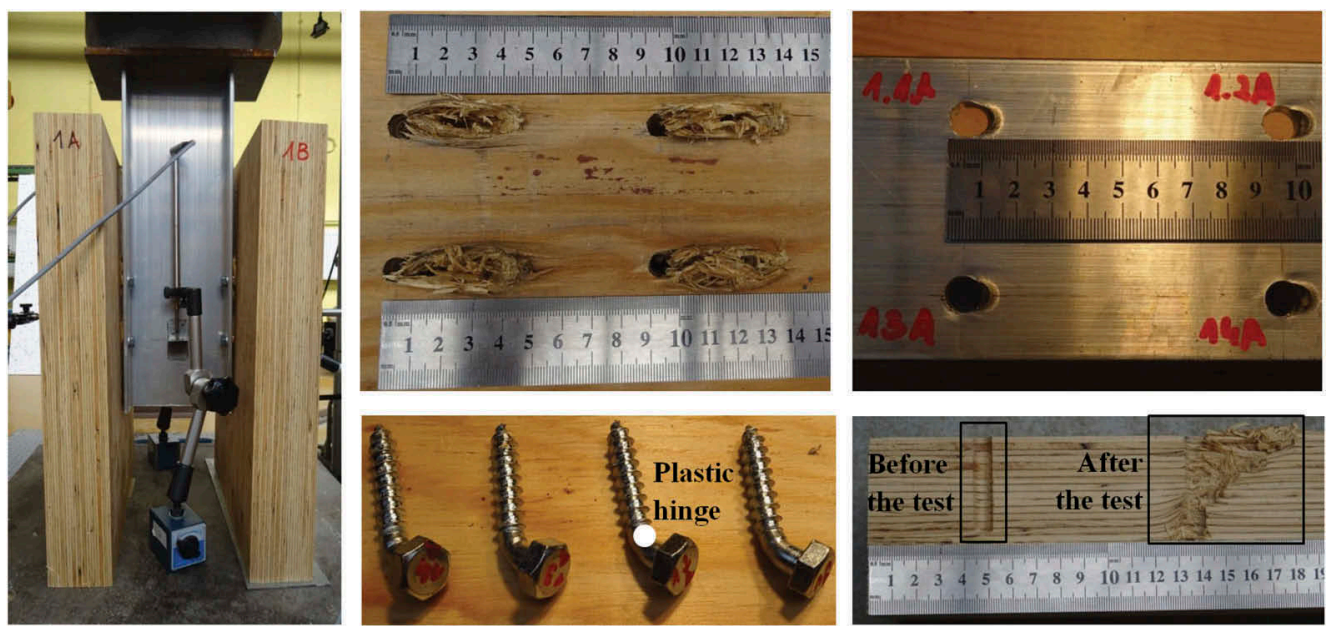

Figure 3. The push-out test specimen after the test (Chybiński \& Polus 2019).

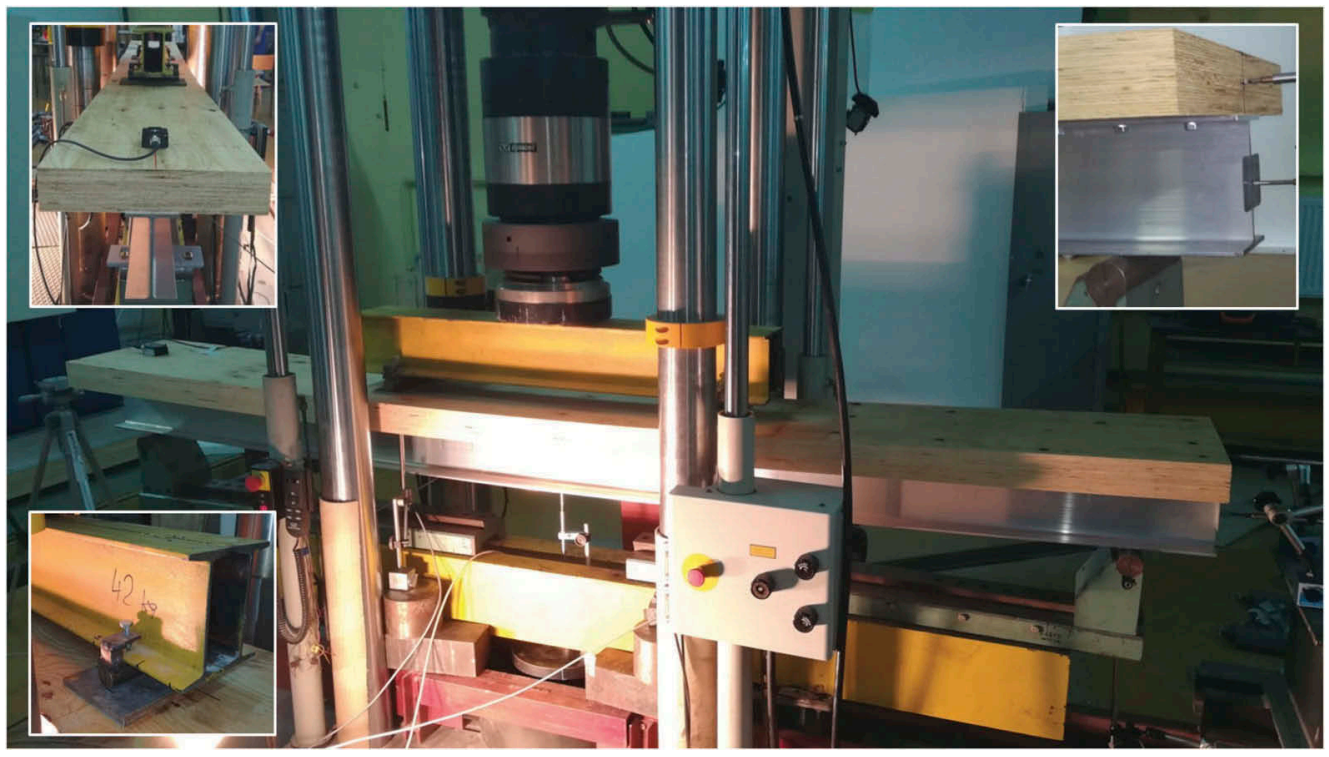

Figure 4. The aluminium-timber composite beam in the bending test (Chybiński \& Polus 2019).

finite element models of the ATC elements used in the bending test and in the push-out test were developed and verified against the experimental results. The shear connections were modelled using zero-length springs. The comparison of the experimental and numerical results demonstrated that the adopted numerical models were able to adequately capture the response of the ATC elements (Chybiński \& Polus 2019).

\section{CONCLUSIONS}

The ACC beams analysed by Polus and Szumigała (2019a) were beams with partial interaction, i.e., the degree of the shear connection was 0.79 , because the connectors could 
only be placed in the ribs of the profiled sheeting. The clearance between the bolt and the hole made it easier to install the shear connectors in the aluminium beam flange. However, it had a negative impact on the connection stiffness $\left(k_{0.4}=5.9 \mathrm{kN} / \mathrm{mm}\right)$. The stiffness of the connection can be increased by tightening the connectors with a higher torque (pre-tensioning) (Rehman et al. 2018) (Kozma et al. 2019) and/or by reducing the clearance (Suwaed 2017). The connections presented by Polus and Szumigała (2016, 2019a) showed brittle behaviour, which was caused by the rib-shear failure resulting from the small width of the profiled sheeting ribs. Furthermore, the analysed connections showed a lower level of slip capacity $(4.2 \mathrm{~mm})$. For this reason, the use of profiled sheeting with wider ribs and of the waveform reinforcement presented by Patrick (2000) to prevent the rib-shearing failure is recommended. The load bearing capacity of the aluminium beams analysed by Polus and Szumigała (2019a) $(22.3 \mathrm{kNm})$ increased 3.2 times (to $72.2 \mathrm{kNm}$ ) after they were joined with concrete slabs.

The ATC beams analysed by Chybiński and Polus (2019) were almost full-composite beams, i.e., the degree of the shear connection was 0.97 . Their flexible connections $\left(k_{0.4}=5.5\right.$ $\mathrm{kN} / \mathrm{mm}$ ) had an impact on the stiffness of the ATC beams. However, the connections were ductile, and the failure mode appeared in the middle of the ATC beam, where a sudden tensile fracture was observed. The load bearing capacity of the aluminium beams analysed by Chybiński and Polus (2019) $(18.3 \mathrm{kNm}$ ) increased 3.4 times (to $62.8 \mathrm{kNm}$ ) after they were joined with LVL slabs.

The bending resistance of the novel structural solutions presented in this paper was calculated using the method for steel-concrete composite elements with partial shear connection and compared with the experimental results. The proposed method of calculating the bending resistance of the composite beams with aluminium girders produced similar results to the bending tests. However, only four ACC beams and two ATC beams were tested. Therefore, it is advisable to perform complementary tests on ACC and ATC beams of different geometries and to verify the method against a greater number of experimental results.

When it comes to numerical modelling, the behaviour of shear connections can be modelled using zero-length springs, the load-slip behaviour of which is obtained in laboratory push-out tests.

It should be noted that the serviceability limit state criterion may be more difficult to satisfy than the ultimate limit state criterion when designing composite beams with aluminium girders because of the low value of the Young's modulus of aluminium.

\section{REFERENCES}

Abendroth, R.E., Sanders, W.W. \& Mahadevan, V. 1996. A continuous span aluminium girder concrete deck bridge, Final Report, Part I: Field Test Performance and Evaluation. Bridge Engineering Center, Iowa State University.

Abramowicz, M., Berczyński S. \& Wróblewski, T. 2020. Modelling and parameter identification of steel-concrete composite beams in 3D rigid finite element method. Archives of Civil and Mechanical Engineering 20, article 103, doi: 10.1007/s43452-020-00100-7.

Bruzzese, E., Cappelli, M. \& Mazzolani, F.M. 1989. Experimental investigation on aluminium-concrete beams. Construzioni Metalliche 5: 265-282.

Chen, Y., Feng, R. \& Xu, J. 2017. Flexural behaviour of CFRP strengthened concrete-filled aluminium alloy CHS tubes. Construction and Building Materials 142: 295-319.

Chybiński, M. \& Polus, Ł. 2018. Bending resistance of metal-concrete composite beams in a natural fire. Civil and Environmental Engineering Reports 4(28): 149-162.

Chybiński, M. \& Polus, Ł. 2019. Theoretical, experimental and numerical study of aluminium-timber composite beams with screwed connections. Construction and Building Materials 226: 317-330.

Chybiński, M., Polus, Ł., Ratajczak, M. \& Sielicki, P. 2019a. The evaluation of the fracture surface in the AW-6060 T6 aluminium alloy under a wide range of loads. Metals 9(3), article 9030324, doi: 10.3390/ met9030324.

Chybiński, M., Polus, Ł., Szwabiński, W. \& Niewiem, P. 2019b. FE Analysis of Steel-Timber Composite Beams. AIP Conference Proceedings, 2078, article 020061, doi: 10.1063/1.5092064. 
Gwóźdź, M. 2007. Project problems of contemporary aluminium structures. Czasopismo Techniczne 104 (z. 4-A): 281-286.

Hanus, J.P., Ray, J.C., Bank, L.C. \& Velazquez, G.I. 2008. Optimized design and testing of a prototype military bridge system for rapid in-theater construction. In J.A. Parmentola \& A.M. Rajendran (eds.), Proceedings of the 25th US Army Science Conference, Transformational Army Science and Technology Charting the future of $S \& T$ for the Soldier, Tech Science Press.

Hassanieh, A., Valipour, H.R. \& Bradford, M.A. 2016. Experimental and numerical study of steel-timber composite (STC) beams, Journal of Constructional Steel Research 122: 367-378.

Komorowski, M. 2017. Manual of design and build in the STEICO system, Basic information, Building physics, Guidelines. Warsaw: Forester Communication.

Kossakowski, P., Wcislik, W. \& Bakalarz, M. 2017. Selected aspects of application of aluminium alloys in building structures. Structure and Environment 9(4): 256-263.

Kozma, A., Odenbreit, C., Braun, M.V., Veljkovic, M. \& Nijgh, M.P. 2019. Push-out tests on demountable shear connectors of steel-concrete composite structures. Structures 21: 45-54, doi: 10.1016/j. istruc.2019.05.011.

Kożuch, M. \& Lorenc, W. 2019. Stress concentration factors of shear connection by composite dowels with MCL shape. Archives of Civil and Mechanical Engineering 19(1): 32-46.

Kyvelou, P., Gardner, L. \& Nethercot, D.A. 2018. Finite element modelling of composite cold-formed steel flooring systems. Engineering Structures 158: 28-42.

Lacki, P. \& Derlatka, A. 2017. Strength evaluation of beam made of the aluminum 6061-T6 and titanium grade 5 alloys sheets joined by RFSSW and RSW. Composite Structures 159: 491-497.

Lee, S.S.M. \& Bradford, M.A. 2013. Sustainable composite beam behaviour with deconstructable bolted shear connectors. In The World Congress on Advances in structural engineering and mechanics (ASEM13), Jeju, Korea, 8-12 September 2013: 3188-3199.

Marcinowski, J. 2018. Stresses in a layered, composite structure fabricated from materials of different thermal expansions. Materiaty Budowlane 4: 107-109.

Mazzolani, F.M. 2006. Structural applications of aluminium in civil engineering. Structural Engineering International 16(4): 280-85.

Nijgh, M., Gîrbacea, A. \& Veljković, M. 2018. Optimization of a composite (steel-concrete) floor system for fast execution and easy demolition. In 14th International Scientific Conference on Planning, Design, Construction and Building Renewal Conference, iNDiS, Novi Sad, 21-23 November 2018: 45-52.

Patrick, M. 2000. Experimental investigation and design of longitudinal shear reinforcement in composite edge beams. Progress in Structural Engineering and Materials 2: 196-217.

Polus, Ł. \& Szumigała, M. 2016. Tests of shear connectors used in aluminium-concrete composite structures. In: M. A. Giżejowski, J. Marcinowski, A. Kozłowski \& J. Ziółko (eds.), Recent Progress in Steel and Composite Structures: Proceedings of the XIII International Conference on Metal Structures (ICMS2016), Zielona Góra, Poland, 15-17 June 2016: 113-136. Boca Raton: CRC Press.

Polus, Ł. \& Szumigała, M. 2019a. An experimental and numerical study of aluminium-concrete joints and composite beams. Archives of Civil and Mechanical Engineering 19(2): 375-390.

Polus, Ł. \& Szumigała, M. 2019b. Theoretical and numerical analyses of an aluminium-concrete composite beam with channel shear connectors. Engineering Transactions 67(4): 535-556.

Rehman, N., Lam, D., Dai, X. \& Ashour, A. F. 2018. Testing of composite beam with demountable shear connectors. Proceedings of the Institution of Civil Engineers, Structures and Buildings 171(SB1): $3-16$.

Saleh, S.M. \& Jasim, N.A. 2014. Structural behavior of timber aluminum composite beams under static loads. International Journal of Research in Engineering and Technology 3(10): 1166-1173.

Siwowski, T. 2006a. Aluminium bridges - past, present and future. Structural Engineering International 16(4): 286-293.

Siwowski, T. 2006b. Prediction of the flexural behaviour of "aluminium-lightweight concrete composite girder”. In M. Giżejowski, A. Kozłowski, L. Ślęczka \& J. Ziółko (eds.), Progress in Steel, Composite and Aluminium Structures, Proceedings of the XI International Conference on Metal Structures (ICMS 2006), Rzeszow, Poland, 21-23 June 2006: 236-237. London: Taylor \& Francis Group.

Siwowski, T. 2009. Structural behaviour of aluminium bridge deck panels. Engineering Structures 31: $1349-1353$.

Stonehewer, J. 1962. A study of composite concrete-aluminum beams, Master of Engineering, Montreal: McGill University.

Studziński, R. \& Ciesielczyk, K. 2019. Connection stiffness between thin-walled beam and sandwich panel. Journal of Sandwich Structures \& Materials 21(6): 2042-2056.

Suwaed, A.S.H. 2017. Development of novel demountable shear connectors for precast steel-concrete composite bridges, $\mathrm{PhD}$, Warwick: University of Warwick. 
Szelka, J. \& Kamyk, Z. 2013. Kompozytowe mosty wojskowe. Budownictwo i Architektura 12(2): 63-70.

Szewczyk, P. \& Szumigała, M. 2018. Static equilibrium paths of steel-concrete composite beam strengthened under load. Civil and Environmental Engineering Reports 28(2): 101-111.

Szmigiera, E. 2007. Influence of concrete and fibre concrete on the load-carrying capacity and deformability of composite steel-concrete columns. Journal of Civil Engineering and Management 13(1): $55-61$.

Szumigała, M. \& Polus, Ł. 2015. Applications of aluminium and concrete composite structures. Procedia Engineering 108: 544-549.

Szumigała, M., Chybiński, M. \& Polus Ł. 2017. Preliminary analysis of the aluminium-timber composite beams. Civil and Environmental Engineering Reports 27(4): 131-141.

Szumigała, M., Chybiński, M. \& Polus Ł. 2019. Stiffness of composite beams with full shear connection. IOP Conference Series: Materials Science and Engineering 471, article 052083, doi: 10.1088/1757-899X/ $471 / 5 / 052083$.

Xu, Y., Wang, Q., Xie, M. \& Wei, Q. 2020. Shear behavior of reinforced concrete beams strengthened with aluminum alloy sheets. Huazhong Keji Daxue Xuebao (Ziran Kexue Ban)/Journal of Huazhong University of Science and Technology (Natural Science Edition) 48(2): 47-53.

Yu, X, Xing, G. \& Chang, Z. 2020. Flexural behavior of reinforced concrete beams strengthened with near-surface mounted 7075 aluminum alloy bars. Journal of Building Engineering 31, article 101393.

Zhou, F. \& Young, B. 2009. Concrete-filled aluminium circular hollow section column tests. Thin-Walled Structures 47: 1272-1280. 